\title{
Characteristics and Productivity of Volcanic Rock Aquifers in Kola Diba Well Field, North-central Ethiopia
}

\author{
Mukrab Kassune ${ }^{1}$, Nata T. Tafesse ${ }^{2, *}$, Miruts Hagos ${ }^{3}$ \\ ${ }^{1}$ MS Consultancy, Addis Ababa, Ethiopia \\ ${ }^{2}$ Department of Geology, University of Botswana, Botswana \\ ${ }^{3}$ Department of Earth Science, Mekelle University, Ethiopia
}

Copyright $\subseteq 2018$ by authors, all rights reserved. Authors agree that this article remains permanently open access under the terms of the Creative Commons Attribution License 4.0 International License

\begin{abstract}
Characterization the different volcanic rock aquifers and evaluation of their respective productivity was done in Kola Diba well field $\left(221 \mathrm{~km}^{2}\right)$, north-central Ethiopia. Collections and analyses of pertinent secondary data were followed by detailed field investigation. Geological and structural investigations was conducted in the field paying particular attention to the different features of the overlying sediments and underlying volcanic rocks units that made them to be a water bearing formations. The structural data were analyzed using Stereonet v7.3 software. Hydrogeological logs, Semi-log scale (specialized plot) and Log-Log scale (diagnostic plot) were prepared to determine the different aquifer types and also to characterize the nature of each aquifer. Inventory of groundwater structures (boreholes and hand dug wells) were also conducted as part of hydrogeological investigation. Pumping test data were collected from ten deep wells and were analyzed using Theis and Neuman methods using Aquifer Test v3.5 software. Stratigraphically, the geology of the area from bottom to top is aphanitic basalt, porphyritic basalt and alluvial sediments. The rocks are affected by different degree of weathering and fractures. The geological formations of the area are categorized hydrogeologically into intergranular and fractured medium and fracture medium. The major aquifers are confined, unconfined and leaky. Hydraulic conductivity values of these different aquifers ranges from 0.0048 to $1.46 \mathrm{~m} /$ day with mean of $0.444 \mathrm{~m} /$ day, transmissivity ranges from 0.5 to $474 \mathrm{~m}^{2} /$ day and specific capacity ranges from 0.026 to $0.88 \mathrm{l} / \mathrm{sec} / \mathrm{m}$ with mean values of $86.878 \mathrm{~m}^{2} /$ day and $0.32588 \mathrm{l} / \mathrm{sec} / \mathrm{m}$, respectively. On the basis of their corresponding transmissivity and specific capacity value, the different aquifers of the studied area were categorized into four aquifer potentiality groups: moderate to low, low to weak, weak and very weak aquifers potentiality. Any future development of groundwater should be focused on the moderate to low
\end{abstract}

potentiality aquifers.

Keywords Aquifer, Groundwater, Hydraulic Conductivity, Hydrogeology, Transmissivity

\section{Introduction}

\subsection{General}

Water is an essential component for all life forms on the earth. Although generally abundant, it is not well distributed in quantity and quality in the globe.

Surface and sub-surface waters are the main sources of water supply for different activities. Groundwater is the sub-surface water that occurs in the saturated zone of variable thickness and depth. Interconnected fractures and pores in the existing rocks and unconsolidated materials make up a large underground reservoir where part of precipitation is stored [1]. This reservoir, which has the ability of storage and transmission of water through it, is called aquifer. Aquifer characterization takes into account the type and nature of the aquifer and how the aquifer gets being a water bearing nature [2].

The study area, Kola Diba well field in Amhara National Regional State, is currently serving as a source of groundwater supply for the Kola Diba and Gonder towns, and for many industries located in and around Gonder town. Ten boreholes are found drilled in different parts of the well field: two for the water supply of the Kola Diba town and the remaining eight for Gonder town. Further are also being planned to be drilled for the water supply purpose of the Gonder town.

Moreover because of absence of other alternative resources in these towns, many private sectors and non-governmental organizations use groundwater for 
different purposes. The future population growth of the towns and the development of the towns themselves will inevitably continue to place an increasing demand on this precious resource. In the long run, due to the increasing of drilled wells and resource consumption this resource will face over groundwater exploitation.

Geologically, the volcanic rocks and alluvial sediments are the most dominant units that cover the study area. Weathered and fractured volcanic rocks are the main aquifer of the area. In the study area well site location are carried out based on surface geological and electrical resistivity methods. Vertical electrical sounding method is the one that commonly employed. Hydrogeological characterizations of the different volcanic rock aquifers and their respective productivity nature, which is the aim this research, have not yet been done. This research was done to fill such gaps and by then to contribute for sustainable development of groundwater in the well field.

\subsection{Location}

The study area, Kola Diba well field is located in Dembia Wereda, North Gonder Zone of Amhara Regional State, north-central Ethiopia. Geographically, the catchment is located between the UTM coordinates of 313000 to $330000 \mathrm{~m} \mathrm{E}$ and 1367,000 to $1380,000 \mathrm{~m} \mathrm{~N}$, having an aerial coverage of about $221 \mathrm{~km}^{2}$ (Fig.1). The well field is part of Tana Sub Basin.

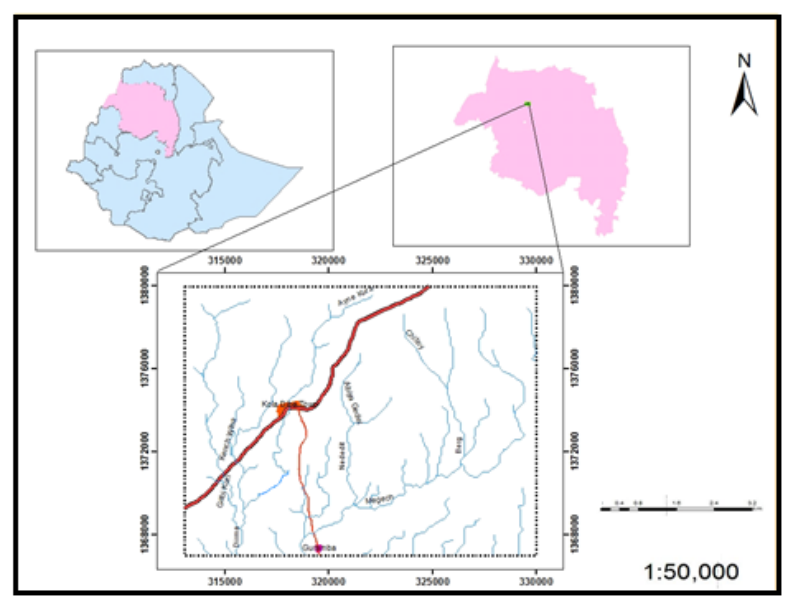

Figure 1. Location map of the study area

\subsection{Geology}

The Cenozoic volcanic rocks of Ethiopia were divided into the Trap Series and Aden Series by Mohr [3]. The term Trap Series is still widely used to refer to the whole pile of the Tertiary flood basalt sequence with intercalation of silicic rocks (commonly on the upper part) which form the northwestern and southeastern plateaus and attain a thickness of up to $3 \mathrm{~km}$. The name Aden Series was used for the post-rift (Middle Miocene to Quaternary) volcanic rocks of the Main Ethiopian Rift (MER), Afar Depression and some parts of the Ethiopian plateaus.

The existence of these Cenozoic volcanic rocks in the country gives rise to three distinct volcanic sub-provinces: pre-rift plateau, Afar rift and the Ethiopian rift. According to Yirgu [4], two major phases of magmatic activity are recognized, which resulted these volcanic sub-provinces in the country: a phase responsible for the eruption of lavas that built thick successions of fissural basalts and later emplacement of thick series of silicic lavas mainly in the form of ignimbrites sheets and a phase of magamatic activity in the in the Afar depression and along the Main Ethiopian Rift $[5,6]$. The second phase is associated with the opening of the interconnected Red Sea - Afar - Gulf of Aden young oceanic rift system and the continental East African rift. The rift that opened along the Red Sea and Gulf of Aden separated the Arabian and African continents, and isolated a small portion of the volcanic plateau in Yemen and Saudi Arabia [7, 8].

The study area is situated on the pre-rift plateau volcanic sub-provinces (covered by Trap Series) that are located in north central parts of the country, which is part of the north western plateau of the country. It consists of flood basalts and shield volcano [4, 9, 10 and 11], and are the result of the first phase lava eruption.

According to Hofmann [9], most of the Ethiopian flood basalts, including the northwestern plateau, erupted $30 \mathrm{Myr}$ ago, during a short $1 \mathrm{Myr}$ period, to form a vast volcanic plateau. Immediately after this peak of activity, a number of large shield volcanoes developed on the surface of the volcanic plateau, after which subsequent volcanism was largely confined to regions of rifting $[10,11]$.

The mineralogical and chemical composition of the flood basalts is relatively uniform. Most are aphyric to sparsely phyric, and contain phenocrysts of plagioclase and clinopyroxene with or without olivine [12]. Most have tholeiitic to transitional compositions [10, 11 and 13]. Interlayered with the flood basalts, particularly at upper stratigraphic levels, are felsic lavas and pyroclastic rocks of rhyolitic, or less commonly, trachytic compositions [14].

In north central parts of the country, the Trap Series/Tertiary flood basalt pile averages $1000 \mathrm{~m}$ to 1500 $\mathrm{m}$ in thickness. The stratoid succession of the Trap Series in these parts of the country comprises of four major formations, all diachronous: from bottom to top, Ashangi (an ascribed Eocene age remains disputed), Aiba (32-25 $\mathrm{Ma})$, Alaji (32- $15 \mathrm{Ma})$, and Termaber (30-13 Ma) [15, 10 and 11].

It is now generally accepted that in the Ethiopia Plateau the Trap Series was formed in the course of two clearly separate cycles of eruptions, namely the Ashangi Cycle (50-35 MY), the older part, and the younger post Ashangi Cycle (32-15MY) [16].

The geology of the study area is consisting of rocks ranging from Tertiary to the recent in age (Figs. 2 and 3). Stratigraphically, from the bottom to the top are the aphanitic basalt, porphyritic basalt and alluvium. The detail 
of each of this geological unit is described as follows.

\section{Aphanitic Basalt}

These units are supposed to be the oldest unit in the study area (Oligocene-Miocene), which is Ashangi basalt. It is exposed typically in the northwestern part of the study area having $14.57 \%$ areal coverage. The aphanitic basalt is characterized by black fresh color and grayish black weathered color, fine-grained rock with no visible phenocrysts and shows high degree of weathering and fracturing.

Several flows essentially comprising alternating strata of amygdaloidal porphyritic and aphanitic basaltic units are seldom separated by reddish brown/ violet paleosol. Volcanic breccia and reworked tuffs appear in between the flows.

\section{Porphyritic Basalts}

These are found forming plateau and dome shaped topography that have a slope ranging from steep to flat. They have black fresh color and grayish black weathered color with large crystals of plagioclase feldspar, biotite and muscovite grown over the groundmass as phenocrysts. It is characterized by fine grained rock with visible phenocrysts and shows slight weathering and fracturing. This unit covers northeastern part of the study area and shows slightly weathering and fracturing having 14.53\% areal coverage. From the stratigraphy observed in the study area, this unit is supposed to be Aiba basalt.

\section{Alluvium}

Extensive alluvial sediments covers northeastern, northwestern and southern margin of the study area overlying the volcanic rocks. It is found at the base of mountain or hill and at the foot of a northern fault escarpment. This unit is presumably the recent sedimentary deposit in the area. The sediments do not have the same thickness, composition and grain size throughout the area in which they are exposed.

It is deposited at the flood plains of Megech River and its tributaries on Lake Tana plain. Megech River is a major river that drains the area toward Lake Tana. Compositionally, it is clayey on low land whereas along the river banks the composition is ranging from silt to gravel having poorly sorted nature. The shape of the individual grains in the gravel range from rounded to sub rounded and the size of the grain is ranging from $2 \mathrm{~mm}$ $12 \mathrm{~cm}$. In the river bank exposures, the deposits have coarse materials (boulder) at the bottom of the channel and fine materials (silt and clay) at the top. Mud cracks having different aperture and lateral extent are common in the southern part of the area where clay is the dominant sediment. Generally, the thickness of the alluvium ranges from 13 - 40m.

\subsection{Geological Structures}

The study area is dissected by fractures and faults oriented in N-S, NNE-SSW, NW-SE, E-W, ENE-WSW direction. The NNE-SSW faults are the oldest structures in the region, and they had played great role to reveal the present Tana graben. The faulted blocks average $1-4 \mathrm{~km}$ width, strike NNE-SSW, and dip east into the Tana basin. They, therefore, contribute to the basin structure. Although the individual tilted, blocks dip at angles of $15^{\circ}-20^{\circ}$ to the east [17].

The N-S trending faults are frequently observed in the northern parts of the study area. There is also subsidiary NW-SE and ENE-WSW oriented sets of structures. They are normal faults generally tilted to the east and southeast directions. The trend of joints and fractures generally conforms to the trend of major faults. The drainage pattern of the area is controlled by the interplay of these faults. Some of the measured structure orientations are plotted in rose diagram and is given in Figure 4 below.

In the horizontally fractured and scarcely vertically fractured and weathered aphanitic basalt, the fractures varies in aperture from 0.5 to $20 \mathrm{~cm}$ and spacing between fractures varies from 70 to $150 \mathrm{~cm}$. In the vertically fractured aphanitic basalt, the vertical fractures vary in aperture from 0.01 to $2 \mathrm{~cm}$ and spacing between fractures vary from 0.1 to $100 \mathrm{~cm}$. These fractures facilitate the flow of groundwater through the rock unless they are filled with cementing material. 

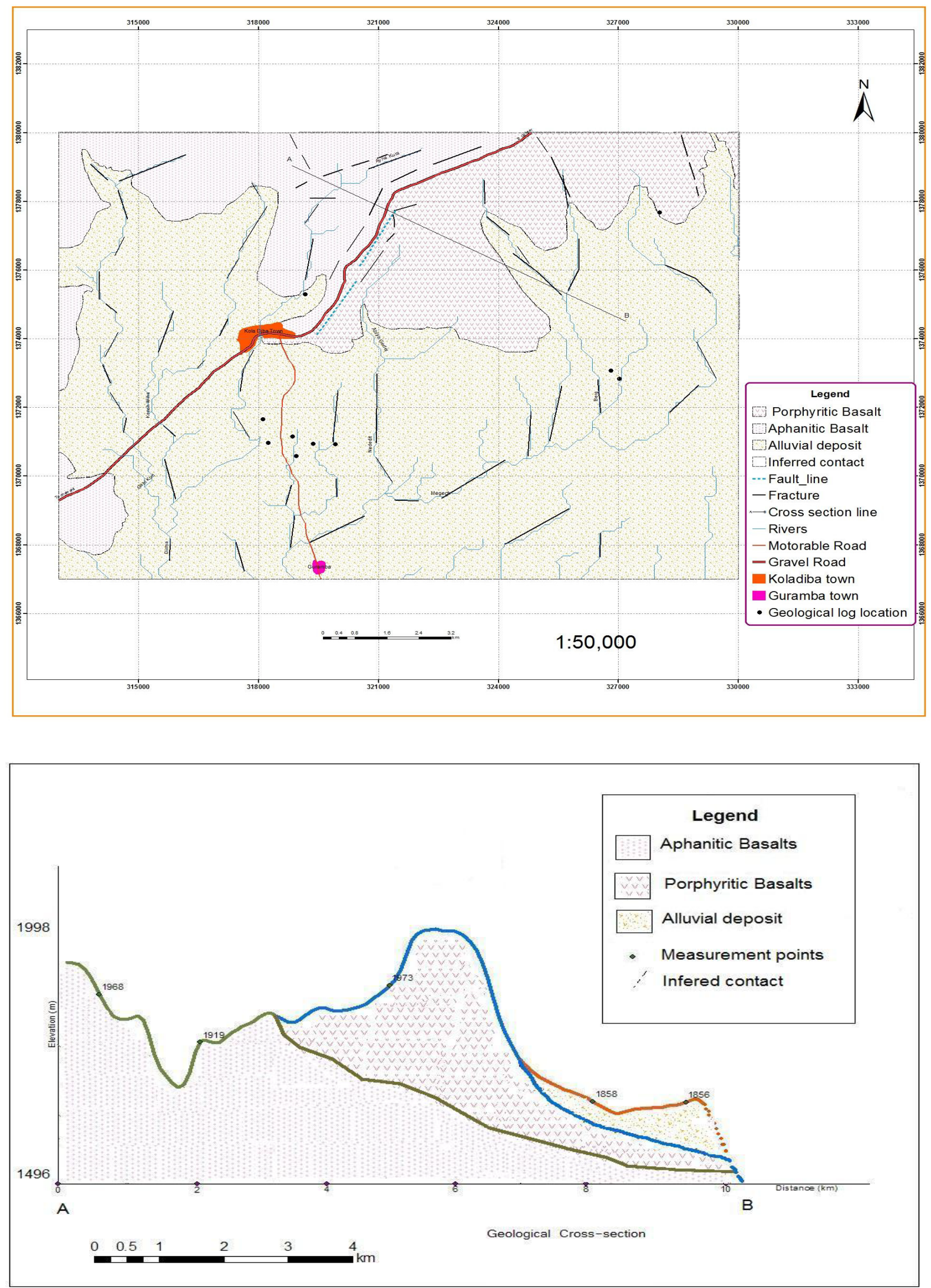

Figure 2. Geological map of the study area and the cross section along AB 


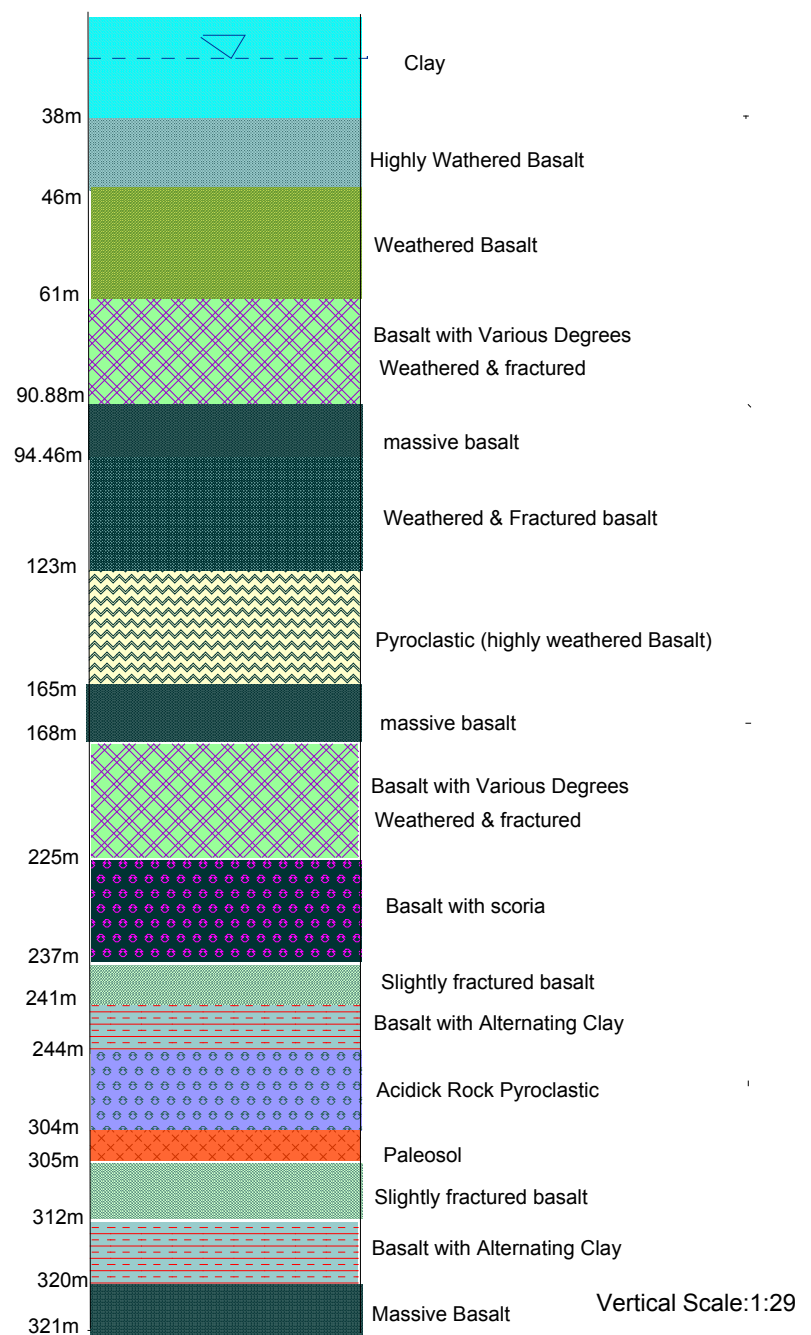

Source: Gonder Town Water Supply and Sanitation Service \& Amhara Water Works Construction Enterprise (AWWCE).

Figure 3. Lithological logs for a well TPW6 $(0318244 \mathrm{mE}$ $/ 1370977 \mathrm{mN})$.

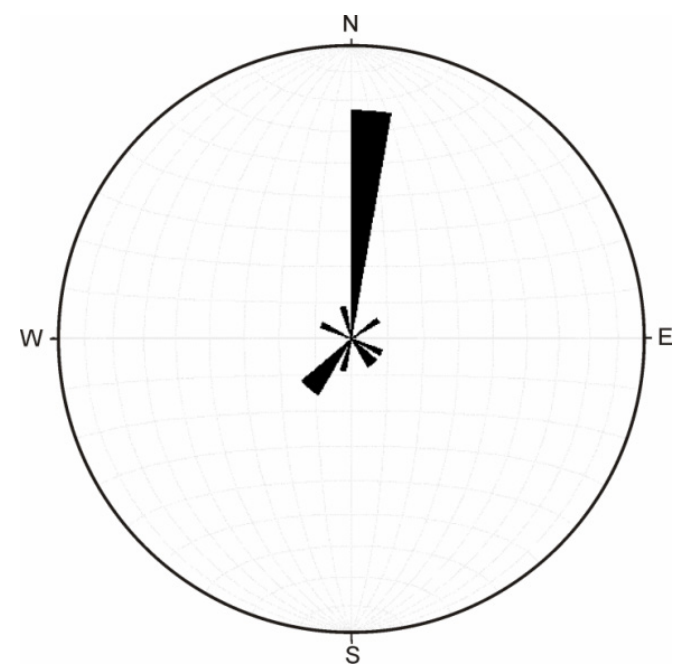

Figure 4. Rose diagram for some measured fractures

\section{Methods}

Different methods have been used to achieve the objectives of this research. Delineation of the study area was done from available topo maps using different software's, and then finalized by taking GPS readings at different sites of the study area for ground checking.

Collections of pertinent documents, previously done regional and nationwide geological and hydrogeological maps, different studied documents around the study area, geological logs and pumping test data of the existing boreholes in the study area from different organizations were done. Data for geology and hydrogeology were collected in the field with the help of GPS. Using Arc GIS 9.3 software, various thematic maps such as location, geological and hydrogeological were produced.

Geological and structural investigations as a technique was conducted in the field paying particular attention to the different features of the overlying sediments and underlying volcanic rocks units for groundwater storage and transmission. The structural data were analyzed using Stereonet v7.3 software.

Inventory of groundwater structures (boreholes and hand dug wells) were conducted as part of the hydrogeological investigation. Hydraulic properties of the different aquifers were determined from the pumping test data and geological logs, which were collected from ten deep wells. The data were analyzed using AquiferTest v.3.5 software by Thies and Numan graphic methods on the basis of the aquifer types.

To determine the different aquifer types and also to characterize the nature of each aquifer besides to the preparation of hydrogeological logs, plots of pumping test data on semi-log scale (specialized plot) and Log-Log scale (diagnostic plot) were prepared for different deep wells and the drawdown behavior were compared with the various theoretical models. Theoretical models comprise the type of aquifer and initial and boundary conditions [18]. According to this author, specialized plots are specific to a given flow system. Diagnostic plot allows the dominating flow regimes to be identified.

\section{Results and Discussions}

\subsection{Types of Aquifers}

From the available pumping test data, a log-log and semi-log plots of drawdown versus time were constructed and the drawdown behavior was compared with the theoretical model (figs. 6 to 8). This technique of comparison reveals the existence of three main types of aquifer in the studied area: unconfined, confined and leaky aquifers. 

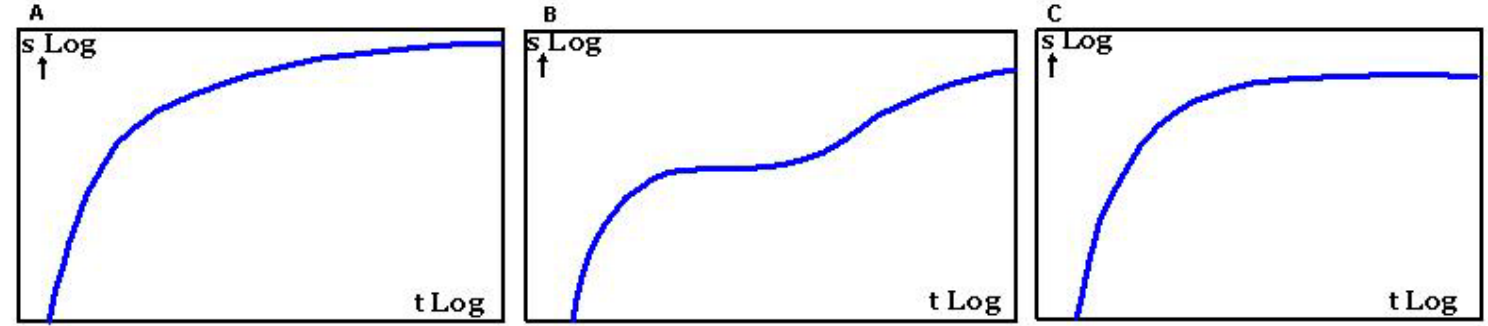

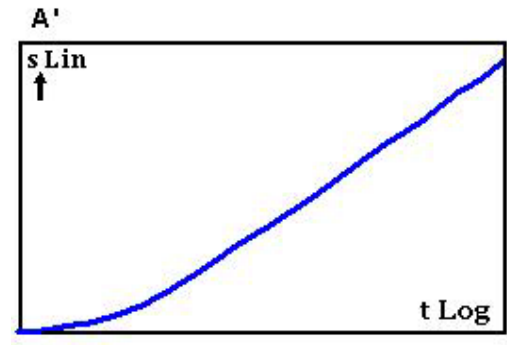

Confined aquifer

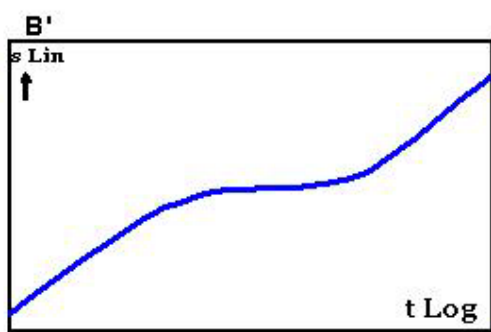

Unconfined aquifer

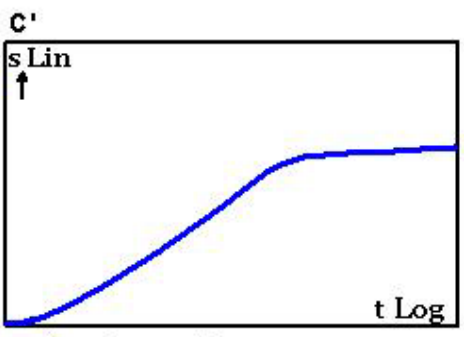

Leaky aquifer

Figure 5. Log-log and semi-log plots of the theoretical time-drawdown relationships for confined, unconfined, and leaky unconsolidated aquifers

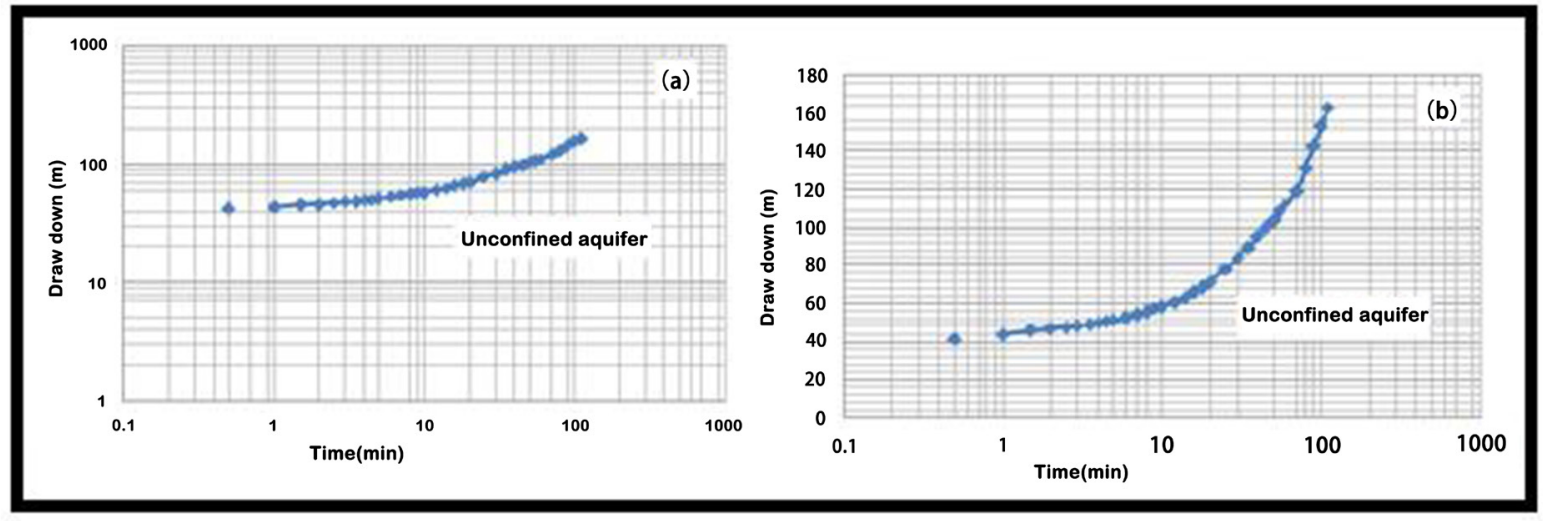

a) Log-log drawdown vs. time for TPW1. b). Semi-log drawdown vs. time for TPW1.

Figure 6. a \& b) Diagnostic and specialized plots of TPW1 deep wells.

This well (Fig. 6) shows a characteristic feature of unconfined aquifer. It is less extensive aquifer, and serve as a source of groundwater for most of the hand dug wells, which are partially penetrated well.
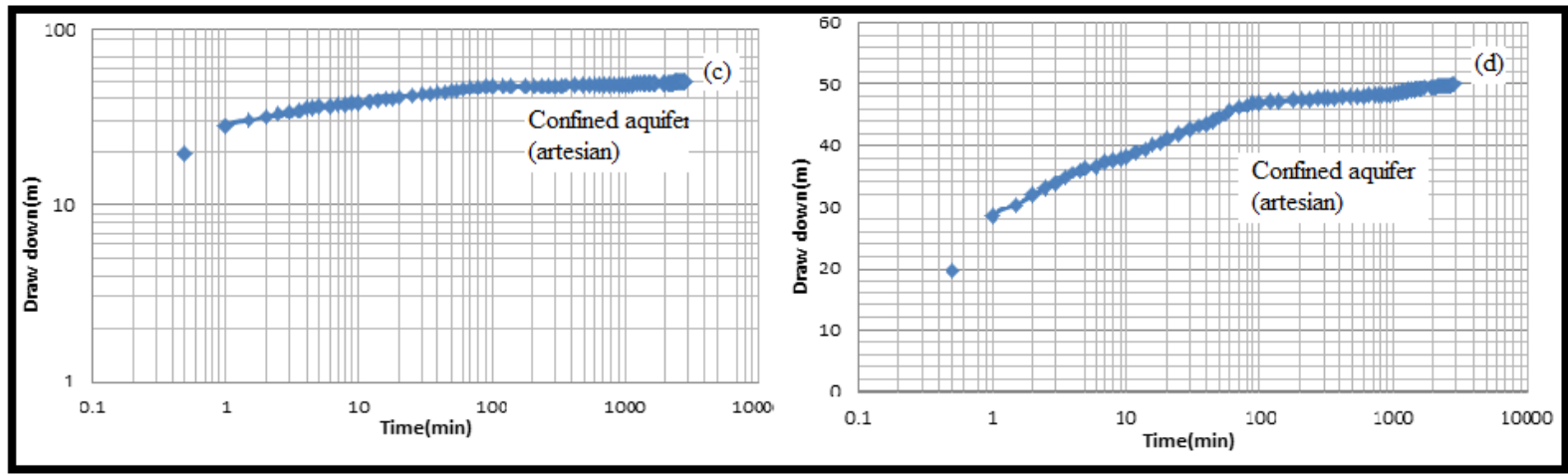

c) Log-log drawdown vs. time for TPW4.

d). Semi-log drawdown vs. time for TPW4.

Figure 7. $\quad$ \& d) Diagnostic and specialized plots of TPW4. 


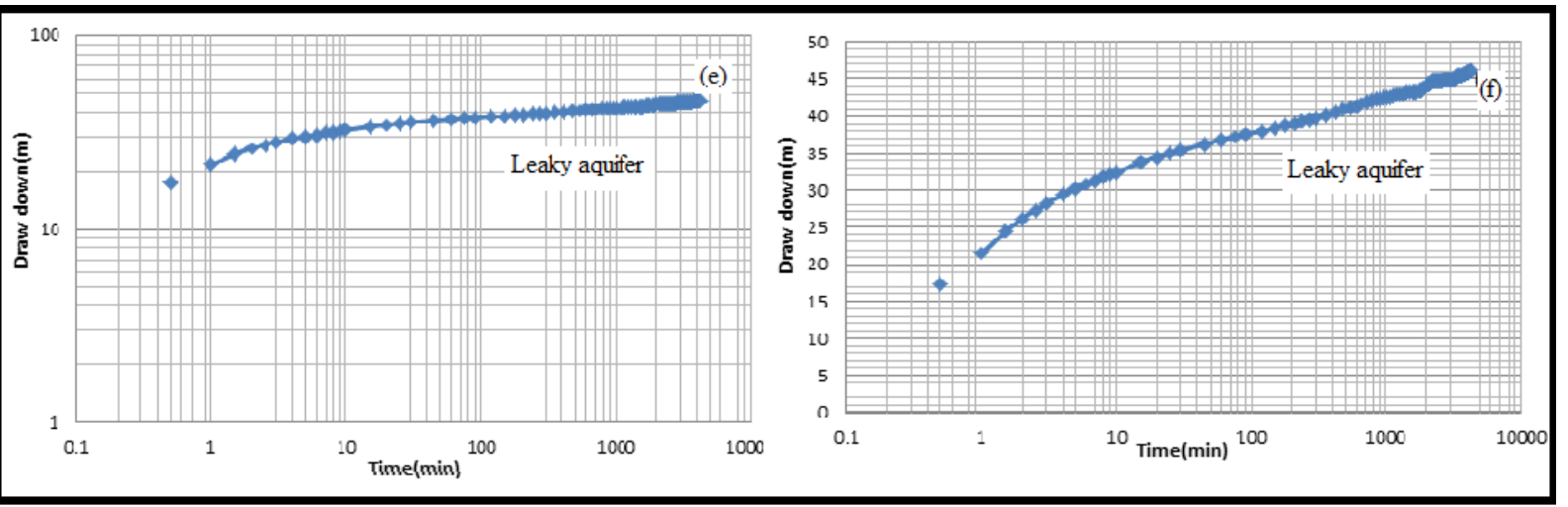

e) Log-log drawdown vs. time for TPW8. f). Semi-log drawdown vs. time for TPW8.

Figure 8. e \& f) Diagnostic and specialized plots of TPW8.

This well (Fig. 7) shows a characteristic feature of confined aquifer. It is a multilayer confined aquifer with extensive areal extent. A pumping test data collected from a deep well, TPW8, shows that the aquifer that serves as a source of groundwater for the well is a leaky aquifer (Fig. $8)$.

In general, the aquifers in the alluvial terrain are unconfined whereas the aquifers in the volcanic terrain are rather complex; multilayer unconfined-confined, multilayer confined, multilayer confined-leaky, and multilayer unconfined-confined-leaky aquifers are found having different thickness and extent.

Based on the type of permeability and porosity which they exhibit and the extent of aquifer, the volcanic rocks and unconsolidated sediments in the area, which host groundwater, are classified into the following two aquifer types.

- Extensive aquifers with intergranular and fracture porosity and permeability (alluvial sediments and basalts); and,

- $\quad$ Less extensive aquifers with fracture porosity and permeability (basalts).

\subsection{Aquifer Characteristics}

The geological situations of the study area suggest a complicated hydrogeological environment and a complex groundwater regime. Alluvial sediments are found covering almost 71 percent of the total area whereas volcanic rocks of different types are found exposed on the surface on the remaining 29 percent of the total area. Based such occurrence, hydrogeologically these geological formations are categorized in to two medium: intergranular and fractured, and fracture.

\section{Intergranular and fractured medium}

Alluvial sediment and the underlying basalt together as one unit constitute an extensive aquifer that is characterized by the presence of both intergranular and fracture porosity and permeability. However, the alluviums don't have the same characteristics in all the area where they are found.

Alluvial deposits in the southern part of the study area are dominantly black clay. These sediments are saturated but poorly permeable stratum that impedes groundwater movement and does not yield water freely to wells. Consequently, they are characterized by a very low permeability and productivity nature, and serve as confining or semi-confining layers (Fig. 9).

Alluviums along the margins of the Megech and Dirma rivers and their tributaries are the most common shallow groundwater aquifers that can be tapped by hand dug wells. Their permeability and productivity vary from place to place depending on their grain size, sorting and thickness.

The underlying volcanic rocks possess fracturing, weathering and other discontinuities, which facilitate storage and movement of groundwater through them. These fractures and discontinuities that may have developed because of pressure and temperature differences during and/or after their formation increased their porosity as well as their capacity for water transmission and enable them to provide potential groundwater reservoirs. Hydrogeologically, this aquifer had good permeability and productivity nature. Due to this, in most cases exploitable groundwater occurrence is limited in the zones of weathering and fractures.

In general in the studied area where the course alluvium are found overlying different weathered and fractured volcanic rocks, the yield of the aquifers is found to be high. 


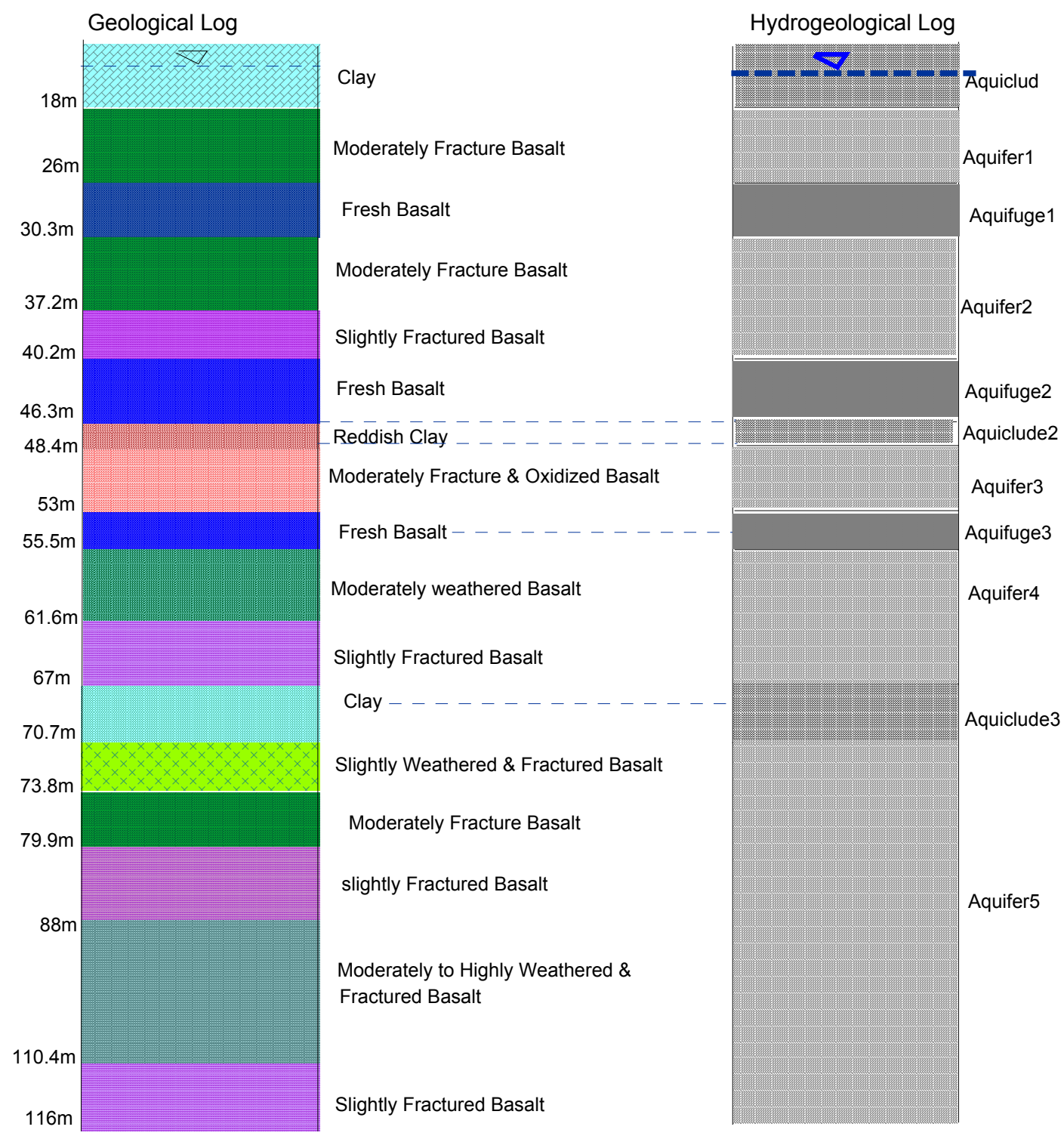

Vertical scale 1:12

Figure 9. Geological versus hydrogeological log of well drilled in multilayer confined aquifer (northwestern part of study area at malt factory1).

\section{Fractured Medium}

This is a medium where the weathered and fracture zones are the only source of groundwater (Fig. 10). However, the extent and thickness of the weathered and fractured zones, the existence of fine pyroclastic deposits associated with lava flows and paleosols in between lava flows limited the occurrence of the exploitable groundwater in this medium.

The presence of vertical and horizontal fractures significantly increases the water circulation and storage capacity of massive aphanitic and porphyritic basalt. However, the same rocks show difference in hydraulic property depending upon the fracture spacing, extent, openings and interconnectivity. The permeability becomes high in areas where basalts are intensively affected by weathering and intersected by networked fractures.

\subsection{Aquifer Productivity}

The basic aquifer properties that were considered for evaluating the aquifer potentiality are the transmissivity (T), hydraulic conductivity (K) and specific capacity. Out of the total available 13 deep wells, three of them lack pumping test data and two lack geological logs. The pumping test data of the ten deep wells were analyzed and the aquifer properties were determined.

Accordingly, the computed values of hydraulic conductivity ranges from 0.0048 to $1.46 \mathrm{~m} /$ day with mean value of $0.444 \mathrm{~m} /$ day. The results of the analysis also reveal that transmissivity ranges from 0.5 to $474 \mathrm{~m}^{2} /$ day and specific capacity ranges from 0.026 to $0.88 \mathrm{l} / \mathrm{sec} / \mathrm{m}$ 
with mean values of $86.878 \mathrm{~m}^{2} /$ day and $0.32588 \mathrm{l} / \mathrm{sec} / \mathrm{m}$, respectively. This variation of both hydraulic conductivity and transmissivity is a result of differences in intensity of weathering, degree of fracturing and interconnectivity nature of fractures in the volcanic rock units. Due to this variation of intensity of weathering, degree of fracturing and interconnectivity nature of fractures, a marked heterogeneity in aquifer characteristics exists both laterally and with depth in the volcanic rock units of study area.

In this research, based on the analyzed result of transmissivity and specific capacity, an attempt was made to classify the aquifers of the study area into different class of potentiality. This classification was made on the basis of Şen [19] scheme. This scheme of classification is given in
Table 1.

Table 1. Classification of wells based on their transmissivity and specific capacities (Source: Şen [19]).

\begin{tabular}{|c|c|c|c|}
\hline $\begin{array}{c}\text { Transmissivity } \\
\left(\mathrm{m}^{2} / \text { day }\right)\end{array}$ & Potentiality & $\begin{array}{c}\text { Specific capacity } \\
(\mathrm{Q} / \mathrm{sw}) \text { in }[(1 / \mathrm{s}) / \mathrm{m}]\end{array}$ & Well productivity \\
\hline $\mathrm{T}>500$ & High & $\mathrm{Q} / \mathrm{s}_{\mathrm{w}}>5$ & $\begin{array}{c}\text { Highly } \\
\text { productive }\end{array}$ \\
\hline $50<\mathrm{T}<500$ & Moderate & $0.5<\mathrm{Q} / \mathrm{sw}<5$ & $\begin{array}{c}\text { Moderately } \\
\text { productive }\end{array}$ \\
\hline $5<\mathrm{T}<50$ & Low & $0.05<\mathrm{Q} / \mathrm{s}_{\mathrm{w}}<0.5$ & Low productive \\
\hline $0.5<\mathrm{T}<5$ & Weak & $\begin{array}{c}0.005<\mathrm{Q} / \mathrm{s}_{\mathrm{w}}< \\
0.05\end{array}$ & $\begin{array}{c}\text { Very low } \\
\text { productive }\end{array}$ \\
\hline $\mathrm{T}<0.5$ & Very weak & $\mathrm{Q} / \mathrm{s}_{\mathrm{w}}<0.005$ & $\begin{array}{c}\text { Very weak } \\
\text { productive }\end{array}$ \\
\hline
\end{tabular}

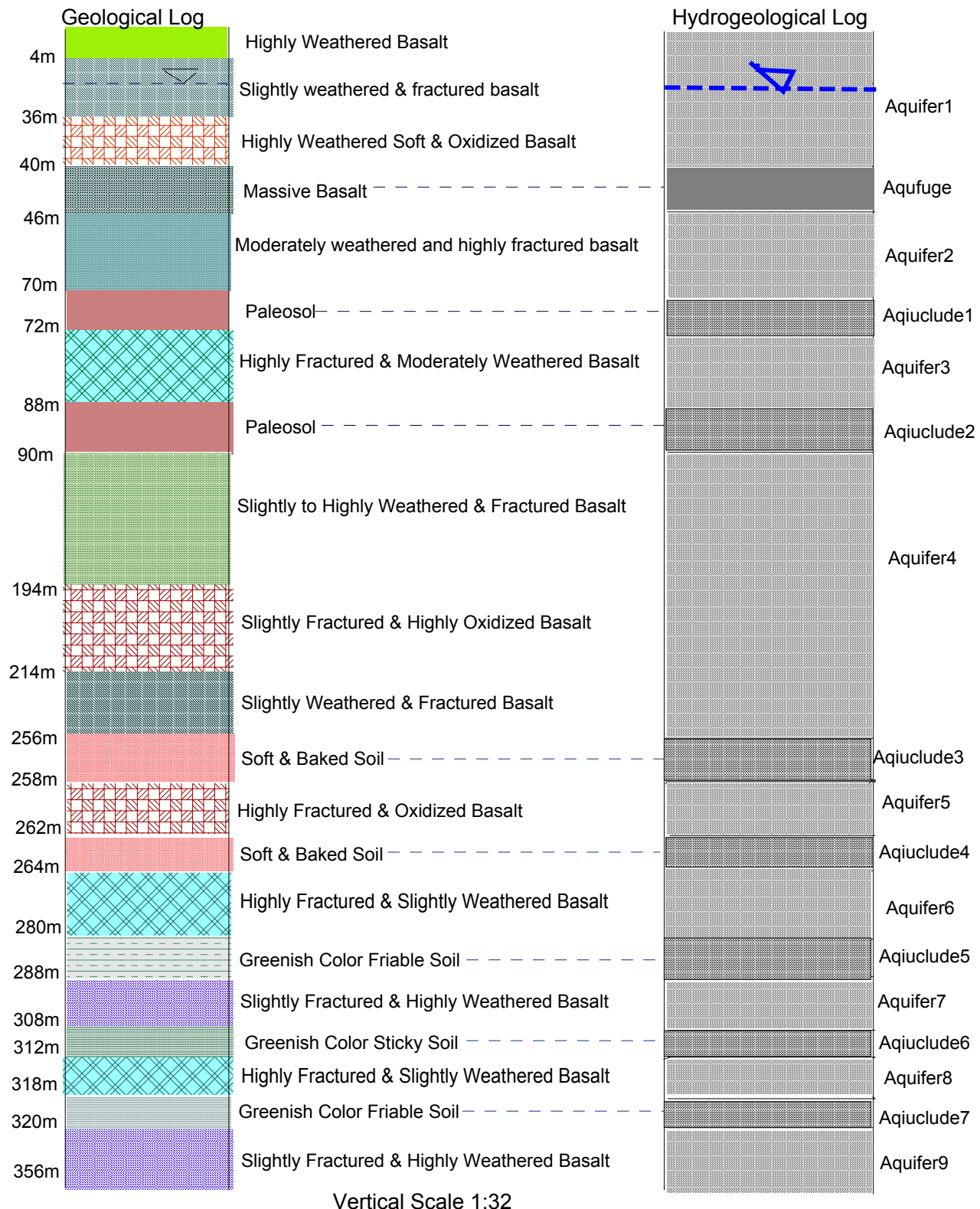

Vertical Scale 1:32

Figure 10. Geological versus hydrogeological log of well drilled in multilayer unconfined Aquifer (North Eastern part of study area at TPW1), 
Accordingly, the alluvium and volcanic rocks of the study area are grouped into four-aquifer group (Fig. 11). These are:

1. Moderate to low aquifers potentiality (Alluvial sediments and underlying basalt);

2. Low to weak aquifers potentiality (Alluvial sediments and underlying basalt, basalt).

3. Weak Aquifer potentiality (Alluvial sediments and underlying basalt, basalt)

4. Very Weak Aquifer Potentiality (basalt)

Moderate to Low Aquifer Potentiality

These are found in the southern, southwestern and southeastern parts of the study area occupying topographically low land areas with a slope ranging from $0-2 \%$ where the alluviums that are dominantly clay are found overlying highly weathered and fractured aphanitic basalts. Some paleosol varieties are also found between lava flows.

The aquifers are multilayer confined aquifers, and their overall thickness ranges from 59.9 to $117.78 \mathrm{~m}$. A number of boreholes, which have a depth ranging from $64-361 \mathrm{~m}$, are found drilled in these parts of the study area and tapping groundwater from such aquifers. The yield of the boreholes ranges from $11.4-37.5 \mathrm{l} / \mathrm{s}$.

\section{Low to Weak Aquifer Potentiality}

Some parts in the north, western and northwestern parts of the study area are characterized by the presence of this aquifer type. The aquifer is found occupying topographically undulating areas that have a slope ranging from $0-14 \%$. Alluvial sediments overlying weathered and fractured aphanitic basalt are found covering these parts of the study area. Some geological logs of the boreholes drilled in this aquifer reveal the existence of intercalation of fine grained sediments that have a thickness ranging from 2 to $3.7 \mathrm{~m}$ between basalts. The aquifers are multilayer confined aquifers, and the overall thickness of them is ranging from 34.8 to $40.18 \mathrm{~m}$. The depth and yield of the boreholes range from 110 to 116.5 $\mathrm{m}$ and 1.3 to $4 \mathrm{l} / \mathrm{s}$.

\section{Weak Aquifer Potentiality}

Aquifers of such type are found in the north, northeastern, central, eastern and southeastern pats of the study area occupying topographically undulating areas that have a slope ranging from $2-23 \%$. The alluvium overlaying aphanitic and porphyritic basalts is a general stratigraphy of the area. However, this is not true for the whole area. In the northeastern parts, the overlaying alluviums are absent.

The aquifers are multilayer unconfined-confined and multilayer confined aquifers, having an overall thickness ranging from $106-150 \mathrm{~m}$. The depth and yield of the boreholes range from $320-356 \mathrm{~m}$ and $2.5-4 \mathrm{l} / \mathrm{sec}$, respectively.

\section{Very Weak Aquifer Potentiality}

Such aquifers are found in southwestern, northwestern, northern and central parts of the study area occupying topographically high and steep area.

Even though the basalts that are found covering these areas are fractured and weathered, the landform that they constitute facilitates runoff rather than percolation. Due to this, the basalts are characterized by high water transmission capacity and negligible water storage ability. The presence of springs at the bottom of these topographically high areas with very low discharge $(<$ $0.11 / \mathrm{s}$ ) confirms such potentiality degree of the basalts.

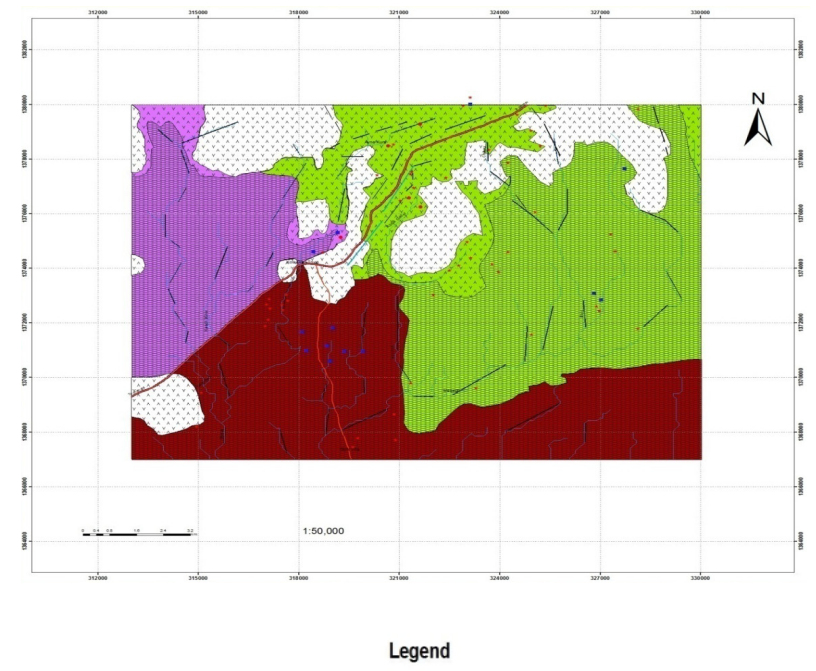

Aquifer Types

圈Extensive Aquifers with Inter-granular and Fracture Porosity and Permeability Less Extensive Aquifer with Fracture porosity and permeability Aquifer Potentiality

Moderate to Low Aquifer Potentiality $(5<T(\mathrm{~m} 2 /$ day $)<50)$

Low to Weak Aquifer Potentiality $(0.5<\mathrm{T}(\mathrm{m} 2 /$ day $)<50)$

Weak Aquifer Potentiality $(0.5<T(\mathrm{~m} 2 /$ day $)<5)$

$\square$ Very Weak Potentiality $(\mathrm{T}(\mathrm{m} 2 /$ day $)<0.5)$

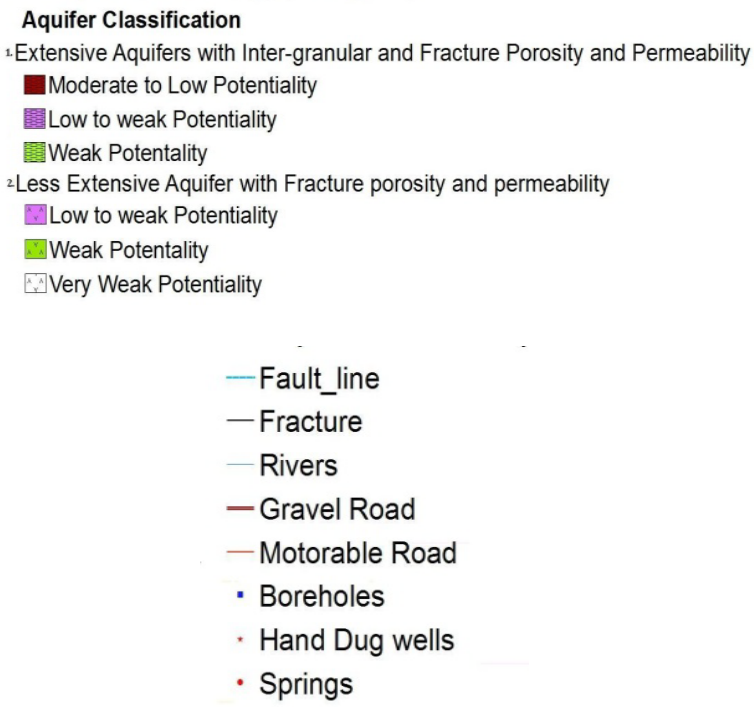

Figure 11. Hydrogeological map of Kola Diba area. 


\section{Conclusions}

The different geological formations that are found constituting the area are categorized hydrogeologically into intergranular and fractured medium and fracture medium. Confined, unconfined, and leaky, which exist as multilayer aquifer system, are the major aquifer types that were identified in the area.

The results of the analysis of pumping test indicate that hydraulic conductivity ranges from 0.0048 to $1.46 \mathrm{~m} /$ day and transmissivity ranges from 0.5 to $474 \mathrm{~m}^{2} /$ day with mean values of $0.444 \mathrm{~m} /$ day and $86.878 \mathrm{~m}^{2} /$ day, respectively. This variation of both hydraulic conductivity and transmissivity is a result of differences in intensity of weathering, degree of fracturing and interconnectivity nature of fractures in the volcanic rock units.

On the basis of their corresponding transmissivity and specific capacity value, the different aquifers of the studied area were categorized into four aquifer potentiality groups: moderate to low, low to weak, weak and very weak aquifers potentiality. Any future development of groundwater should be focused on the moderate to low potentiality aquifers.

\section{Acknowledgements}

The authors duly acknowledge Tana Sub Basin Organization for sponsoring this research work.

\section{REFERENCES}

[1] Garg S.K. (1987). Irrigation Engineering and Hydraulic Structures, Khanna Publishers, India.

[2] Nata Tadesse T. (2010). Basic Principle of Hydrogeology: Basic Concepts and Methods; VDM Verlag Dr. Muller Gmbh \& Co. KG, Germany.

[3] Mohr P.A. (1962). Stratigraphy and correlation of Cenozoic volcanic rocks. Geological Survey of Ethiopia, Addis Ababa, 26 pp.

[4] Yirgu, Y. (1997). Magma-crust interaction during emplacement of Cenozoic volcanism in Ethiopia: Geochemical evidence from Sheno-Megezez are, central Ethiopia. SINET Ethiopian Journal of Science, 20 (1): 49 $-72$.

[5] Gibson, I.L. (1974). A review of the geology, petrology and geochemistry of the volcano Fantale. Bulletin of Volcanology 38: $791-802$.

[6] Di Paola, G.M. (1972). The Ethiopian Rift Valley between $7^{\circ} 00^{\prime}$ and $8^{\circ} 40^{\prime}$ lat. North. Bulletin of Volcanology 36: 317 -356 .
[7] Chazot, G. and Bertrand, H. (1993). Mantle sources and magma -continental crust interactions during early Red Sea -Aden rifting in Southern Yemen: elemental and $\mathrm{Sr}, \mathrm{Nd}, \mathrm{Pb}$ isotope evidence. Journal of Geophysical Research 98, $1818-1835$

[8] Menzies, M., Baker, J. and Chazot, G. (2001). Cenozoic plume evolution and flood basalts in Yemen: a key to understanding older examples. In: Ernst, R. E. \& Buchan, K. L. (eds) Mantle Plumes: their Identification through Time, Geological Society of America, Special Papers 353, 23-36.

[9] Hofmann, C., Courtillot, V., Feraud, G., Rochette, P., Yirgu, G., Ketefo, E., and Pik, R. (1997). Timing of the Ethiopian flood basalt event and implications for plume birth and global change. Nature, 389, 838-841.

[10] Mohr, P. (1983a). Ethiopian flood basalt province. Nature $303,577-584$

[11] Mohr, P., and Zanettin, B. (1988). The Ethiopian flood basalt province. In J.D. Macdougall, Ed., Continental Flood Basalts, pp. 63-110. Kluwer Academic, Dordrecht.

[12] Bruno Kieffer, Nicholas Arndt, Henriette lapierre, Florence Bastien, Delphine Bosch, Arnaud Pecher, Yirgu, G., Ayalew,D., Weis,D., Jerram,D.A., Keller, F. and Meugniot, C. (2004). Flood and shield Basalts from Ethiopia: Magmas from the African Suuperswell. Journal of Petrology, Vol. 45, No. 4, 793-834.

[13] Pik, R., Deniel, C., Coulon, C., Yirgu, G., Hoffmann, C. and Ayalew, D. (1998). The northwestern Ethiopian Plateau flood basalts: classification and spatial distribution of magma types. Journal of Volcanology and Geothermal Research: 81, 91-111.

[14] Ayalew, D., Marty, B., Yirgu, G. \& Pik, R. (1999). Geochemical and isotopic $(\mathrm{Sr}, \mathrm{Nd}$ and $\mathrm{Pb}$ ) characteristics of volcanic rocks from southwestern Ethiopia. Journal of African Earth Sciences 29, 381-391.

[15] Zanettin, B., Gregnanin, A., Justin Visintin, E., Mezzacasa, G. and Piccirillo, E.M. (1974). Petrochemistry of the volcanic series of the central-eastern Ethiopian plateau and relationship between tectonics and magmatology, Mem. $1^{\text {st }}$. Miner. Univers. Padova, 31: 1-35.

[16] Zanettin, B. (1993). On the evolution of Ethiopian volcanic province, from Geology and Mineral Resources of Somalia and Surrounding Areas. Ist. Agron. Oltremare, Firenze, Relaz. E Monogr. 113, p. 279-310.

[17] Chorowicz J., Collet B., Bonavia F.F., Mohr P., Parrot J.F. and Korme T. (1998). The Tana Basin, Ethiopia: intra-plateau uplift, rifting and subsidence. Tectonophysics 295 , pp. 351-367.

[18] Kruseman G.P. (1990). Analysis and evaluation of pumping test data, Second edition, International Institute for Land Reclamation and Improvement, Wageningen, The Netherlands.

[19] Şen, Zekâi. (1995). Applied Hydrogeology for Scientists and Engineers. CRS Press, Lewis Publishers, London, pp. 444. 